\title{
Splintering disaster: relocating harm and remaking nature after the 2011 floods in Bangkok
}

\begin{abstract}
In the wake of the costly 2011 floods, the city of Bangkok struggled to respond to the water inundating Thailand's major hub. In response, Thai leaders primarily blamed the external forces of nature and climate change. Depoliticising disasters and absolving national leaders of responsibility, these discourses about nature and climate change as the main cause of flooding led policymakers to primarily build infrastructure to block and drain water. We argue that the location and patterns of flood protection infrastructure reflect flows of power and the circulation of capital. We build upon Graham and Marvin's notion of 'splintering urbanism' to develop the concept of 'splintering disaster'. We do so to make sense of the spatially dispersed, but ideologically unified strategy of flood protection adopted in Bangkok. We argue that the splintered nature of flood infrastructures demonstrates the varied and complex factors that produce new regimes of urban water control in the wake of disasters. As we demonstrate, flood mitigation projects do not foreclose future floodwater, but instead, redistribute nature, risk and injury. The city both shapes and is shaped by this spatially fragmented response to water. We aim to use this concept to develop a conceptual vocabulary for understanding post-disaster infrastructural politics.
\end{abstract}

Keywords: splintering disaster, urban flood governance, 2011 Bangkok flood reconstruction, infrastructure politics, post-disaster political ecology, floodwalls, Thailand flood management

In 20I I, a vast area surrounding the Thai capital of Bangkok was inundated for about two months. Although the floodwater threatened the city's central business district, the focal points of the disaster were at the edges, the rapidly growing peri-urban areas where new housing estates and industrial parks sit amidst rice fields. There, more than a dozen dykes failed, inundating the region and disrupting global supply chains. Central Thailand suffered tremendous losses - over US $\$ 46$ billion - as fetid water gathered and then settled in place for weeks. In the wake of the disaster, the Thai government produced a host of recovery plans and new flood mitigation efforts. Although, some of these plans would have coordinated the country's system of canals and waterways into a coherent flood prevention system at the scale of the national territory, the projects built to date are fragmented, piecemeal and unproven as effective flood management.

This article was published open access under a CG BY licence https://creativecommons.org/licences/by/4.o/

Danny Marks is Assistant Professor in the Department of Asian and International Studies at City University of Hong Kong, ${ }_{3}$ Tat Chee Avenue, Kowloon Tong, Kowloon, Hong Kong; Eli Elinoff is Lecturer in the School of Social and Cultural Studies at Victoria University of Wellington, PO Box 6oo, Wellington 6r4o, New Zealand; e-mail: danny. marks@cityu.edu.hk; eli.elinoff@vuw.ac.nz 
Why has the Thai government persisted with this ad hoc strategy? What are the socio-political effects of these splintered post-disaster infrastructures? These two questions are rooted in local and non-local connections to the 20I I floods and provide areas of inquiry addressed under the 'splintering disaster' framework. To consider these questions, we explore three case studies: first, a major highway that was heightened in the Thung Prapimorn sub-basin in Nakhon Pathom province; second, a proposed dyke along the Chao Phraya River in Pakkret Municipality in Nonthaburi Province; and third, the private floodwalls built around industrial estates in Ayuthaya.

In this article, we examine the contestations produced by the construction of these dispersed disaster infrastructures by developing a concept of 'splintering disaster'. Building on Graham and Marvin's (200I) assessment of neoliberal urban space and its fragmented, unequal topographies of infrastructure, we argue that the sum effects of such systems of flood mitigation are neither coordinated nor well understood. They cannot be understood in post-disaster frameworks that aim to create resiliency or reduce vulnerability. Rather, we argue that these infrastructures should be understood in terms of their specific political contexts and their fragmented spatial arrangements. In this way, they can best be understood by considering their splintering effects with regard to future disasters. In other words, the floodwalls, dykes and embankments built across Central Thailand should not simply be understood as flood protection, but rather as both reflective and constitutive of new environmental and political topographies. In this sense, efforts to understand Central Thailand's post-disaster landscape requires coming to terms with these dispersed flood mitigation projects and making sense of their uncertain, uneven effects on the distribution of future harm (MacCallum et al., 20 I I).

In what follows, we describe our conceptualisation of splintering disaster, casting post-flood projects in light of broader debates about the relationship between the city and its infrastructure, especially flood-control infrastructures. Following this conceptual section, we describe the background to the 20I I floods and describe the three case studies. We conclude by discussing why the government pursued these infrastructural options and their effects. To support our analysis, we present multiple views of community leaders, government officials and activists. These informants have firsthand experience of these projects and their opinions shed light on the projects' uncertainties, inequalities and ambiguities.

\section{Splintering disaster}

In Splintering urbanism (Graham and Marvin, 200i), Steven Graham and Simon Marvin describe the way that infrastructural systems can fragment the urban experience, making fundamentally different cities for different sorts of residents. As they point out, the distribution of pipes, electrical lines and highways fragment the city in socially 
relevant ways, linking some spaces while partitioning others. Such fragmentations they argue are foregrounded in so-called 'networked infrastructures' where anticipations of failures, collapse and uncertainty are part and parcel of infrastructural projects. Following them and the broader turn towards infrastructure in the social sciences (Star, I999; Anand, 20I I; Harvey and Knox, 2012; Larkin, 2013; Anand et al., 2018), we consider the ways post-flood infrastructure projects in Thailand have transformed the environment in uncertain ways, redistributing social life along different lines and becoming critical sites of political action.

Beyond emphasising infrastructures as systems, we consider the social, political and economic processes that give rise to post-disaster infrastructure. Recent writing on infrastructures calls attention to the social, political and economic processes that infrastructures enact as they function, fall apart, and are maintained (e.g. Graham and Thrift, 2007). The material politics of infrastructure are vibrant in the sense that they reveal how seemingly well understood sets of things act out, misbehave, and fail (Bennett, 20I0). This is especially true in the face of disaster, which is defined as an event that outstrips established social, political and physical infrastructures. It is this unruly combination of enchantment (Harvey and Knox, 20I2) and fragility (Connolly, 20I3) that makes post-flood infrastructural projects attractive to state agents. Visions of catastrophes to come (Whitington, 2013) and discourses about the management of uncertainty (Zeiderman, 2015) become critical, generating centralised support for projects whose effects are unknown and often locally divisive. As Star puts it, '[o]ne person's infrastructure is another person's [...] difficulty' (I999, 380).

Infrastructure projects are particularly dense with political resonance because of the ways in which they reshape social relations on the ground (Harvey and Knox, 2012). A focus on processes of infrastructural planning, evaluation and construction helps expose such shifts as they take place. Construction remains a critical political and economic lynchpin everywhere, including in Thailand (Elinoff, 20i7b). Such projects are popular because they appear to demonstrate efficacy and engagement even as they also serve to move money and manpower (i.e. Elinoff et al., 20I7). Concurrently, these projects create suspicion, especially to residents living through post-disaster moments. For example, as van Voorst and Hellman (2015) argue, in Jakarta such uncertainties have been particularly potent in poor communities, where new flood mitigation projects often operate as a pretence for evictions. Uncertainty is compounded by technocratic efforts to manage the unknown via infrastructural strategies that fail to account for the multiple origins of a given catastrophe (Miller and Douglass, 2015). ${ }^{1}$ We suggest that the planning, construction and heightening of floodwalls and other post-disaster projects in Thailand reflect these insights as competing interests converge in the production of a fragmented landscape of dykes and embankments. Guided by

I A turn towards infrastructure, materiality and techno-politics is fundamental for engaging with the complex landscape of disaster politics in urbanising Asia (see Miller and Douglass, 2015). 
our informants' uneasy anticipations regarding the uncertainties inherent in these new infrastructures, we argue that Thailand's post-disaster infrastructures not only fragment contemporary space in uneven ways, but also future disasters still to come.

We read uncertainty, risk and anticipation as fundamental to disaster mitigation projects as they rest on past failures and project yet-unknown topographies of vulnerability. As Guggenheim argues (2014, I3), 'disasters exist and create political (re)arrangements without even happening' (emphasis in original). Engaging with the making of these floodwalls, then, reveals the way in which the uncertainty, fragmentation and ambiguity inherent in their construction are part and parcel of processes of political rearrangement (see also Choi, 2015).

By considering the Thai floodwalls through a notion of 'splintering disaster', our goal is to draw attention to the socio-spatial, political and bio-physical fracturing that occurs through the construction of new disaster mitigation infrastructures. We consider the variegated ways such infrastructures might distribute the effects of future disasters. As our informants repeatedly pointed out, floodwalls simultaneously produce the bifurcated effects of inundated and dry land. Close attention to the political processes through which such infrastructures were created demonstrates the present- and future-tense uncertainties inherent in these infrastructures. The distribution of future disasters and the relationship between flood embankments does not reflect a cohesive strategy, but, rather, specific political valuations of what matters in the present. Although the political-economic value of Bangkok often sits at the centre of planners' calculus, floodwalls were both national and local projects. Within these varied spaces, the walls aim to secure sites that generate wealth and potentially votes while inundating areas considered less valuable. Occasionally these differences reflect the large divisions within contemporary Thai politics, but often, as we show, such differences were cross-cut by local interests. Thus, when considered in relation to specific socio-political, economic and hydrological topographies, the splintering effects of walls implies that their construction is not the enactment of a set of hydrological or political facts. Rather, partitioning via floodwalls reflects intersecting multiscalar debates (Marks and Lebel, 20i6), which entailed the marking of some sites as worthy of protection and others as zones of sacrifice.

The location and patterns of flood-control infrastructure reflect flows of power and the circulation of capital, rather than decisions based on long-term risk calculations (Collins, 20I0). Often the state, rather than the private sector, has undertaken investments in flood risk reduction, such as flood protection structures, designation of public floodways and land-use controls. Therefore, the state plays a key role in determining which individuals are most and least vulnerable to floods. Hence, the state is a crucial arena of contention over flood protection. In this contemporary landscape, the elites have often been able to use the state to accumulate social surpluses in areas where they live, invest, and work at the expense of other groups (ibid.). Studies of 
New Orleans before Hurricane Katrina, for example, revealed that differing levels of vulnerabilities had arisen largely due to pre-existing structural inequalities (Cook and Swyngedouw, 2012). However, the structures of power that govern floods and their effects are not static. By opening political space, floods could act as catalysts or tipping points, shaping 'the future political trajectory towards an accelerated status quo or a critical juncture' (Pelling and Dill, 2010, 22). In this sense, attention to the making of Bangkok's post-flood infrastructures reveals the splintered political topography upon which these floodwalls were constructed. Concurrently, we observe how this splintering can be productive, creating new publics and generating new forms of resistance. Rather than present a coherent picture of Thailand's political interests, attention to these processes reveals the way crosscutting differences were fundamental to the production of these walls and their uncertain effects.

As we will discuss below, the conflicts and inequities at the peripheries of Bangkok's urban floodwalls reflect precisely these concerns. Both the walls themselves and the procedures surrounding their construction demonstrate Thailand's endemic inequalities (Phongpaichit and Baker, 2015). Fragmented layers of governance play out in splintering urban space, political opposition, administrative control and the flood waters themselves.

\section{Context: the $\mathbf{2 0 1 1}$ floods and reconstruction efforts}

The worst flood in Thailand's modern history, the 20I I flood, killed more than 800 people and cost the economy at least US\$46 billion (World Bank, 20 I I). Many of the losses and damage occurred in the Bangkok Metropolitan Region (BMR): the city of Bangkok and the surrounding five provinces. While Thailand did receive heavy rainfall that year, a number of human activities interacted with this heavy rainfall to create the floods. These activities include massive land use change and concretisation, over-pumping of groundwater, and the filling of canals (Marks, 2015).

The failure of flood-control infrastructure also contributed to the high level of devastation experienced during the 20I I flooding. One reason for the failure is that, prior to 20II, local government public work agencies constructed dykes in an ad hoc manner. They tried to address local flooding problems or improve irrigation without creating an integrated plan. Further, since many dykes function as access roads, a different agency - the Department of Rural Roads (DRR) - is responsible for their maintenance. The construction of dykes along riverbanks in many upstream provinces thus reduced the capacity of dykes downstream to handle a once-in-a-hundred-year flood (Manuta et al., 2006).

In 20II, flood-control infrastructure failed along the Chao Phraya, upstream of Bangkok. Eighteen dykes and water gates partially broke because local government agencies had not adequately maintained the ageing structures. Infrastructure 


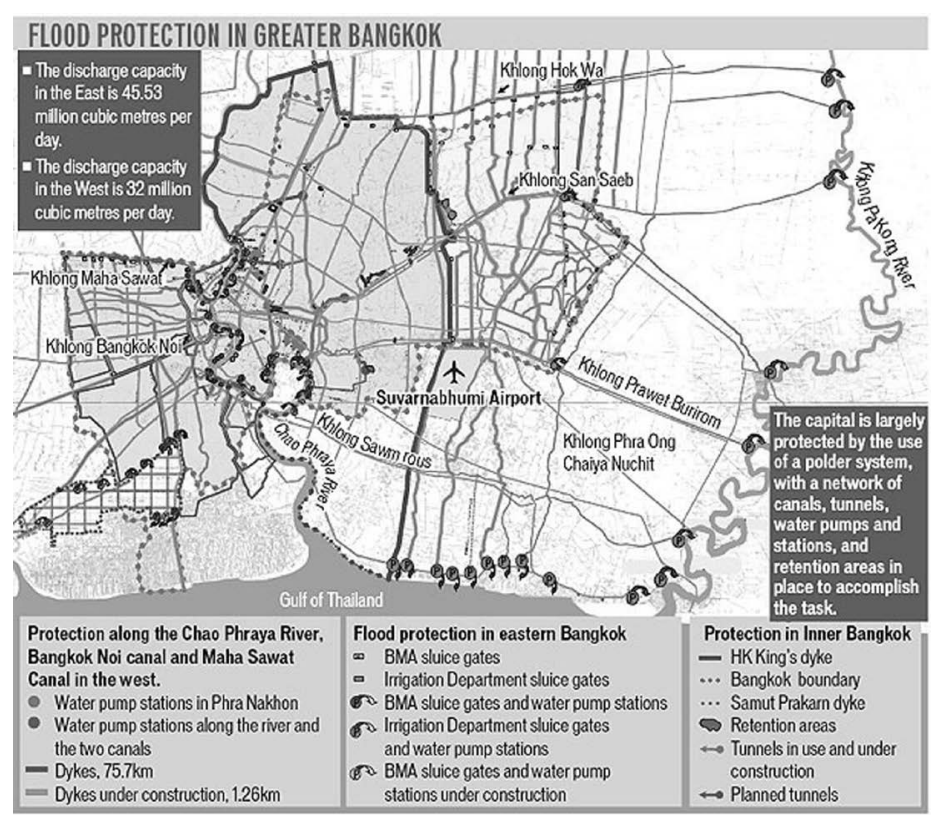

Figure 1 Flood protec-

tion infrastructure in

Greater Bangkok

Source: Fernquest (2011)

failures, especially the Bang Chom Sri water gate in Singburi Province, caused the flood protection embankment along the river to be breached (Poapongsakorn and Meethom, 2013). In addition, the King's Dyke (see Figure I), which is supposed to protect northern Bangkok, was designed primarily to address low-level flooding rather than infrequent but high-level flooding events. Subsequently, the King's Dyke was breached in two places in $20 \mathrm{I}$.

To make matters worse, non-structural measures were insufficient. In particular, the number and size of the retention ponds in the BMR were too small to hold the 20I I floodwaters. In addition, poor regulation of land use contributed to the floods. The excessive pursuit of property development promoted overbuilding in the BMR, including housing estates built illegally in green zones intended to store floodwater, as well as in floodways, such as the industrial estates in Ayutthaya (see Marks, 2015). Poor coordination between provincial governments further weakened land-use planning.

In short, the material forms of urbanisation in Bangkok are not a well understood or clearly mapped topography. Instead, they comprise a murky 'ecology of possibilities' composed of uncertain relations between the pre-existing landscape, infrastructural materiality, humans, non-humans and the regimes of politics and governance that shape them (Elinoff 20I7a). Rather than demonstrating a well-coordinated relationship between water, infrastructure and urban form, the 20I floods revealed the city's hydrological landscape as emergent, contested and unknown. Existing dykes, water gates and temporary flood walls created highly uneven vulnerability to the floods. These infrastructures 
were paired with emergent responses as the Bangkok Metropolitan Administration (BMA) erected huge sandbag barriers, closed water gates, and diverted water to the west to protect the city's central districts. Such protections followed a long-standing centre-focused spatialisation of the Thai polity which imagines the centre of the city as the 'heart' of the nation (Thongchai, I994; Elinoff and Sopranzetti, 2012). As a result, communities on the outskirts of the city were subject to substantial flooding and their assets were heavily damaged, but those living in the inner city stayed dry. At the same time, local politicians and community leaders, seeking to protect their own turf, set up temporary dykes which created numerous conflicts and worsened the overall response to the floods.

During the flood and after it subsided, key government actors, such as the prime minister and deputy prime ministers, blamed the floods on nature, climate change and excessive water. For example, Deputy Prime Minister Plodprasop Suraswadi told us: 'There was too much water. We could not handle it.' Deputy Prime Minister Kittirat Na-Ranong declared that the flooding 'has to be the result of climate change and global warming' (NBC News, 20II). These discourses claiming that too much water was the cause of the flooding led to two potential types of post-flood mitigation projects: (I) accept and live with water by removing polders and using non-structural measures to build resilience to floods (Liao, 2012); or (2) try to block water and keep certain areas dry, thereby potentially creating uneven vulnerabilities. There was widespread anger against the government's immediate response to the floods (see Marks, 20I9). Yet, despite widespread devastation and the high number of deaths, the national government chose the latter option and viewed flood-control infrastructure as the best response to the obvious risks of future flooding.

The national government, then headed by Prime Minister Yingluck Shinawatra of the Pheu Thai Party, proposed a massive 350 billion Baht (\$US I I.7 billion) water infrastructure improvement plan for the nation's waterways. ${ }^{2}$ Approximately 9o per cent of the budget was allocated to manage water in the Chao Phraya River Basin. Included in the plan's nine modules were twenty new dams and two $300 \mathrm{~km}$ diversion floodways to divert water from the north to the west and east and then to the sea (Janseen, 20I3). This infrastructure-heavy plan supports the notion that national leaders deemed engineering solutions as the primary response to reduce the risk of future floods. It was also clear that the project was biased towards addressing flooding in Bangkok. One key project in the plan that was completed was raising a series of roads on the periphery of the BMR. These roads were raised to meet the height of the 20 I f flood waters plus an additional $5^{0} \mathrm{~cm}$ (as seen as the DRR projects in Figure 2). This project cost 8.9 billion Baht.

This plan was met with fierce criticism from civil society, academics and communities, as well as resistance from the judiciary. Civic and engineering groups lambasted the plan for being too expensive and poorly conceived. For example, a water specialist

2 At that time, approximately 30 Baht equalled one US dollar. 


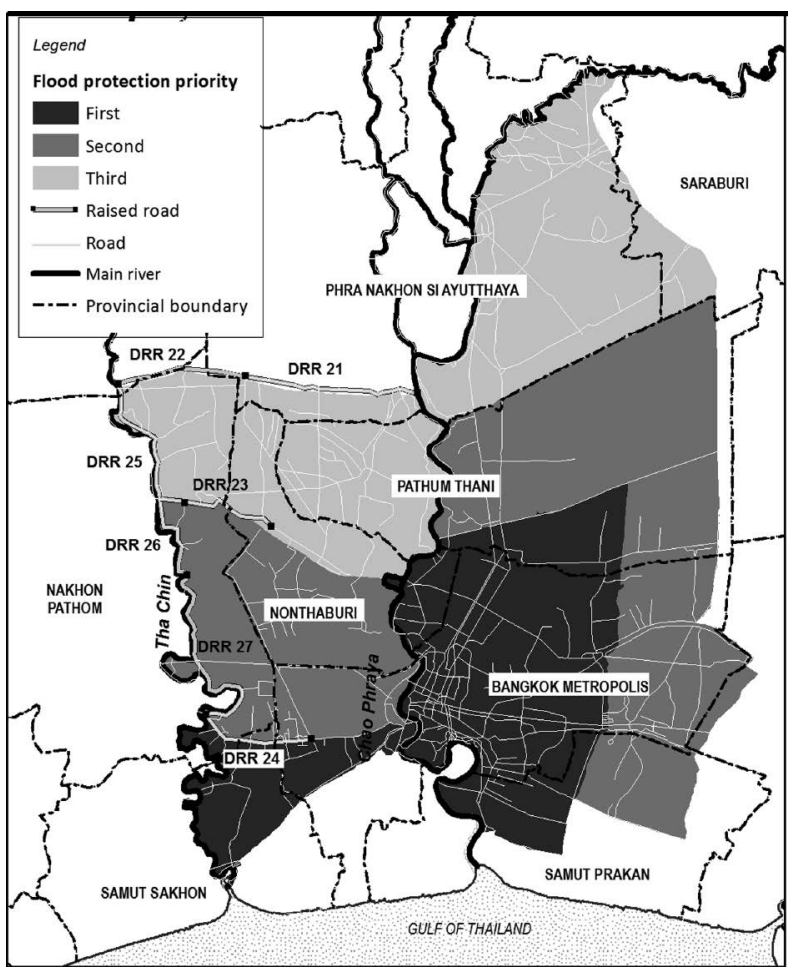

Figure 2 The raised roads in

Central Thailand and the areas

prioritised in this project

Source: Created by Trina Isorena

asserted that from an integrated water management perspective, neither the new dams nor the floodways were necessary. Civil society advocates charged that the government had not sought adequate public input on the plans (Cleanbiz.Asia, 2013).

This fierce opposition to the plan and the military coup of 2014 caused large portions of the plan to remain unbuilt. For example, the government failed to construct a western flood diversion channel, which would have diverted water from the Chao Phraya to the west to protect Bangkok. In Samut Songkhram and Nakhon Pathom provinces, thousands protested against the floodway, declaring that water from it would hurt their fishing and agricultural activities (Attakhor, 2013). Backed by these communities, a local NGO, Stop Global Warming Association of Thailand, filed a lawsuit in Thailand's administrative court. The suit claimed that the bidding procedures for the megaproject violated the constitution: the government had not adequately included local communities in the decision-making process and had failed to carry out mandatory environmental and health impact assessments. In late 20I3, in agreement with the lawsuit, the administrative court ruled that the plan must be put on hold until public hearings and environmental and health impact assessments were conducted (Janseen, 20I3). The military government, which launched a coup in 20I4, decided to scrap the project. 
In June of 20I4 the new prime minister, Prayut Chan-o-cha, ordered agencies to draft a new national water management plan. The military scrapped a few projects of the previous government, in particular the aforementioned floodway in Western Thailand. Other projects were delayed, such as dykes along the Chao Phraya River. During interviews, senior government officials from Royal Irrigation Department (RID) and the government-run Hydro Agro Informatics Institute disclosed that several of the modules of the Yingluck government's plan had been included in the military government's plan. The net result was a patchwork of projects each responding to different topographic and political demands, some local, some national, some transnational. Uncertainty and anticipation are pervasive parts of this unsystematic system.

On the one hand, the flood protection projects proposed in post-20 I Thailand have been read as transforming water into a political resource that used 'flood protection as a populist resource of differential inclusion' (Whitington, 2013, 320). On the other, the crosscutting interests across the Chao Phraya basin makes this populism difficult to characterise in existing political terms. At times, flood protection has responded to industry, and other times to local or national demands. These diverging interests are reflected in the ways in which local governments and the military government built a patchwork of flood projects, some of them as a result of the previous government's plans. These engagements with flood infrastructures reveal the long legacy of the 20I I floods, which, under the rubric of climate change, has transformed into, as Whitington (2013) argues, a 'model event'. Such an event generates political possibilities for multiple actors to re-narrate that event with an aim towards projects targeted at mitigating future disasters. In this sense, we see the post-disaster reconstruction process as not merely an effort to respond to the past event, but also a process which employs that event to forecast and anticipate future transformations.

In the next sections, we describe three projects in the Extended Bangkok Metropolitan Region (EBMR). First, we describe raised road projects in Thung Prapimorn in Nakhon Pathom province. Next, we discuss a proposed project in Nonthaburi, a $29 \mathrm{~km}$ dyke. Finally, we describe the proliferation of flood walls constructed in periurban industrial parks in Ayutthaya Province.

\section{Raising roads in Thung Prapimorn}

DRR projects $\# 24-27$ (the white lines in Figure 2) are the roads that were raised in response to the 20I I floods on the western side of Thung Prapimorn in Nakhon Pathom. The roads sit on the eastern bank of the Ta Chin River, ${ }^{3}$ leaving a small area between the roads and the river. These roads are part of a larger project of DRR

3 This river is a distributary of the Chao Phraya River. It splits near the province of Chai Nat and then flows west from the Chao Phraya through a number of central provinces, including two BMR provinces: Nakhon Pathom and Samut Sakhon. 


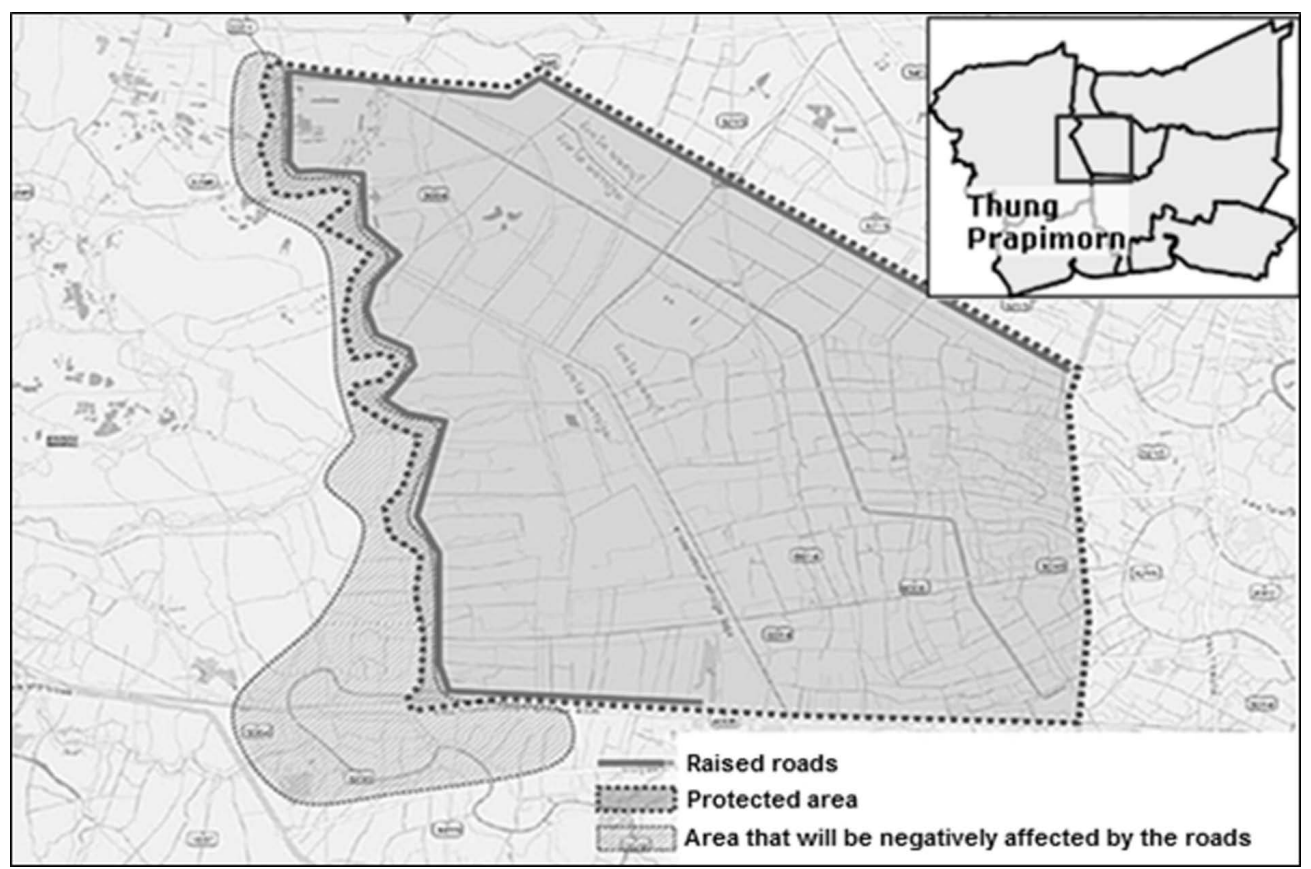

Figure 3 Map of raised roads in Thung Prapimorn and the projected affected areas Source: Thailand Development Research Institute (2015)

2I-27 (Figure 2 and 3). The projects were built to prevent floodwater from entering the Kalong Phraya Banglue in the north of Nonthaburi (DRR 22) and from flowing from the eastern side of the Ta Chin into Nakhon Pathom. The processes behind the construction of these roads intensified local uncertainties surrounding the distribution of water in future floods.

As of 2017 , Nakhon Pathom province is approximately 30 per cent urban and 70 per cent agricultural. Although it is spatially distinct from Bangkok, residents are keenly aware that urban sprawl is quickly remaking the region into a proper urban periphery. Post-flood politics in the province reflect the kinds of crosscutting interests between a national government aiming to protect Bangkok and local interest seeking to understand the environmental effects of new projects as they intersect with the region's emerging peri-urban topographies and trajectories. The case shows how creeping urbanisation and new flood infrastructures challenged local resistance even as national resistance to adjacent projects gained some traction. The new projects reflect multiple splintered publics, thereby raising questions about whether the roads should be raised, what the potential effects of such projects might be, and how potentially affected communities should be compensated for their sacrifices. 
In 2012, the national government began to stealthily raise these roads without conducting an Environmental Impact Assessment (EIA). The I992 Conservation of National Environmental Quality Act normally requires an EIA before these sorts of projects. However, according to a Department of Rural Roads officer, his agency avoided the requirement by dividing the project into four separate, smaller projects (DRR 24-27 - see Figure 2 for a visual representation). In doing so, the national government superseded local authorities and built the project with the expressed aim of protecting Bangkok at the expense of the periphery.

A local government official in Salaya, a town in Nakhon Pathom, complained: 'They didn't tell anybody before raising the road.' Although the government did conduct limited public hearings, it did so only after the project was underway. Even then, only those who lived inside the protected area were invited to attend. National government leaders in charge of the project, such as Plodprasop, instructed the DRR, the agency raising the roads, not to invite people living outside of the road to the hearing. Further, according to a DRR officer, they were told not to inform residents outside the project of the increased likelihood of future floods due to the raising of the roads. An officer in this agency told us that 'if these people had protested or opposed the road, the government would have blamed us'. He added that even though some officers, including himself, disagreed with this project, they followed the government's orders because, 'during that time politics was strong, so people here in this department could not publicly oppose the project even though they do not agree'.

More than one government official disagreed with the DRR 2I-27 project. An officer in the Nakhon Pathom provincial Department of Town and Country Planning likewise believe that this road raising project was a bad idea:

It is built against nature [...] The eastern area is lower than this area. By blocking the water from not going into Bangkok on the East, it is planned to protect overfill from river. But what about rainfall? If it rains on the eastern side, it will be stuck. The area is very low $[\ldots]$ They should instead have another canal to release the water.

Here this officer suggests that although the road was built with the intention to protect Bangkok, it may have an opposite effect because rainwater will stay trapped inside the dyke. In agreement, a DRR officer pointed out that the roads have weak points because water can enter the area inside the dyke through water gates and canals. Further, he thought that the improved roads would spur more housing estates along the road which would further reduce the area's drainage capacity. He stated: 'The water won't have any place to go.'

When interviewed, the heads of the eight Tambon [district] Administrative Organisations (TAO) located outside of the road, all disagreed with the project and believed it would exacerbate future flooding in their areas. This area flooded heavily in 20II. Each of those officials expressed concern that it would flood heavily again in 
the future because of the dyke. For example, one TAO head said: 'Now there is less room for water to flow. The road will be another cause of flooding.' Another added: 'The dyke is not necessary. It's only one solution, which might not work.' In the one district divided by the road, the TAO head agreed that the road would make flooding worse for those on the outside. He added that the 'national government wants the area [outside the dyke] to flood in order to keep Bangkok dry'. Another said that some of those people were misinformed and mistakenly thought that road would protect them from flooding. Those residents also complained that because the road was so high, it was difficult for some houses to access it. One person in the province who defended the project was the unelected deputy provincial governor. He claimed: 'If the road is used for fifty years, for only one year it will be bad.' His justification did not deny the underlying effects of the project, but argued that such sacrifices were necessary and minor. Most of the TAOs felt powerless to oppose the project. For example, the head of one stated: 'The project comes from the central government. We cannot do anything much. We have to receive whatever they order.'

A group of provincial and local government leaders and local activists who had earlier opposed the Yingluck government's proposed western floodway, publicly expressed opposition to the road. In early 2015, approximately seventy of them met and spoke against the project which, similar to the floodway, was initiated by the Yingluck government. Many signed a petition complaining about the road and they submitted the petition to the military government. To date, they have received no response. According to one of the group's leaders: 'We cannot do much now because the project is already done.' This deep-seated disagreement about the project between national political leaders and local leaders and activists suggests different opinions about the location of flood walls and their ambiguous potential effects. Each disagreement raises the question of scale, highlighting the circumscribed boundaries around which spaces should be protected and sacrificed. The distinctions between who would be inundated and who would stay dry were not clear in the construction of the project and thus, the floodwalls reflect a splintered and ambiguous future topography of future disaster.

One tambon head did not sign the petition and did not criticise the project. He asserted: 'It is no problem to raise the road because it is an industrial and economic area [inside the road]; we understand that this will be a flood zone but we need a compensation scheme for our agricultural products.' All of the leaders, regardless of whether they agreed or disagreed with the project, beseeched the government to provide a fair and transparent compensation scheme. Some people in these areas sold their land due to their worry of future floods. Nobody seemed to know whether the residents will be compensated or not in the future.

The raised road project appears to offer a material testament to state efforts to secure residents living inside the dyke, including those in Bangkok, in the face of 
future disaster. But since the project lacks even a basic EIA, the most that can be said about the road's effect on future floods is that it will partition disaster in new and highly uncertain ways. The cumulative effect of the raised roads is clear enough: to divide places into categories, those that appear floodable and those that must stay dry. The debates surrounding the raising of DRR 24-27 Nakhon Pathom reveal how such projects fundamentally splinter residents into different classifications. These classifications are based upon relations with the infrastructure, itself constructed through a fragmented set of processes. This political fragmentation occurs due to the residents' differing perceptions of the ways in which the road could affect their vulnerability to future floods.

\section{Pakkret partitioned}

Pakkret is a city of almost 200,00o located within the BMR. During the 20I floods, most of the city stayed dry due to monumental efforts by the municipal government to build a temporary dyke along the river. However, a few communities outside this dyke experienced heavy flooding. As part of its massive post-flood mitigation project, the Yingluck government proposed to build a $29 \mathrm{~km}$ dyke along the stretch of river running through the Pakkret municipality. Yingluck and Plodprasop visited the city and their government set aside a budget for the dyke but, after the 20I4 coup took place, the military government delayed its construction. In April 20I5, we spoke with a municipal officer who told us that he thinks that, in spite of the coup, the dyke will be built in the next five to ten years.

Within the current design, the vast majority of the buildings and communities in Pakkret, including its inner city, will be inside the dyke while a small minority will be outside. Similar to the raised roads in Thung Prapimorn, this project has generated conflict, tensions between national and local officials and between areas of the city that seem to be relegated to be flooded as a result of to the project's design.

Based on our interviews with a dozen community leaders and government officers, the majority of those who live in Pakkret agree with the construction of the dyke. They believe that it will prevent flooding in most of the city. As one community leader whose community would be protected by the dyke put it: 'The government should build the dyke along the river.' Another echoed his support for the dyke: 'Most people are happy with the project. It will help not only for flood but also for erosion protection. It will stop houses from being destroyed.' Indeed, they said that about 8o-9o per cent of participants in public hearings on the dyke expressed support for the project.

One leader said that those who disagreed with the dyke should change their mind: 'They should think about benefits for the entire city. The world is changing.' The municipality's head of public works also supported the project. He argues that the dyke would protect most of Pakkret from future flooding and would save the munici- 
pality a lot of time and money because it would no longer have to build temporary dykes annually during the rainy season.

Reflecting the uneven split in public hearings on the dyke, a minority of interviewees opposed the project. All of those expressing frustration or opposition with the project were community leaders living outside the project's boundaries. One leader said: 'We are not happy with it. We are frustrated that we will only see the wall behind them instead of seeing the nature and think it will be harder to get inside our houses.' Another added that there is yet to be an EIA or other studies on the dyke. Consequently, she proclaimed: 'People here are still scared of what will happen - if the dyke collapses then water will be stuck here.' She believes that it would be better if 'the water comes, increases, and decrease naturally'. She also lamented that the community does not care about the fishers who would be adversely affected because 'the dyke will block the way out for fishers to catch fish'. She believed fishers were given low priority because fishing 'is perceived as an older generation job, not a new generation job'. In her community, twenty people signed a petition opposing the dyke.

Additionally, municipal and provincial authorities spoke out against the project. The deputy mayor opposed the dyke. He opined: 'The dyke will intensify flooding because if the water is higher than the dyke and comes into the city, then the water will be more damaging and flow faster [...] The scenery would also be destroyed by the dyke.' He also felt the project was too expensive and 'wasted government money'. Similar to local officials in Thung Prapimorn, he felt powerless to oppose the project.

A Nonthaburi provincial leader also disagreed with the project. He stated: 'Even though the project tries to protect one side of the river, areas on the other side will have to more work to prevent floods. Also, those people inside will benefit but those outside will be affected by floods.' His statement suggests that the dyke could cause the exposure to flooding to be more unequal in at both the urban and provincial scale.

The range of opinions expressed by local leaders and residents revealed the complex and uncertain topographies upon which the project was built. Although the project was premised on protecting the majority of the city at the expense of the minority, the long-term effects remain unknown. The proposed dyke in Pakkret has divided not only national and local officials but also local urban communities. Those who thought that their livelihoods and homes would be threatened by the dyke were most opposed to it, whereas those who believed that they would be protected from future floods supported the dyke. While this analysis might seemingly be obvious, we are struck by the way in which the walls reconstituted the city's publics in new ways.

One part of the opposition to the dyke can be understood through the new distribution of water proposed by the dykes. Another part reflects the ways in which the dykes themselves were built outside of a normal process. Without a proper forecasting through an EIA, residents expressed concerns over the project's effects on future floods, livelihoods and the broader efficacy of the dyke itself. A final component of the 
schism reflects the way in which those whose houses had previously been inundated in 20I I understood the way that disasters inherently overrun existing infrastructures (e.g. McFarlane, 20ı, I39). Anticipating the worst, their concerns about the potential effects of the dyke reflect a keen sense of uncertainty. Their anticipations reflect fears that future floods will not only leave their communities open to inundation, but that the new infrastructure will re-partition the city in ways which could effectively erase their communities.

\section{Privatising public protection in Ayutthaya}

The 20II floods created huge losses in Thailand's primary manufacturing zones, which sit on the outskirts of Bangkok in peripheral provinces, such as Ayutthaya. They disrupted supply chains for major auto parts suppliers for Toyota and Honda, and had important impacts on electronics manufacturers like Apple, Lenovo and Samsung (World Bank, 2012). Similar to the discursive framing of the floods as a problem of 'too much water', rather than considering the 80o-plus deaths and millions of affected lives, the amplified focus was on economic losses. This focus enabled industrial estates to begin construction of floodwalls much faster than other state projects.

In Ayuthaya Province, the government provided funding to estates to build towering proprietary walls to protect their businesses when the area floods again. For example, at the Rojana industrial estate, which houses global brands such as Honda, Canon and Nikon, the estate owners obtained two billion Baht (US\$ 66 million) of government funding to build a $77 \mathrm{~km}$ long wall around the perimeter of the property. It consisted of an outer dyke $6 \mathrm{~m}$ above mean level, an inner ring highway $4.5 \mathrm{~m}$ above sea level, and a third wall, 'Rojana's self-protective dyke six metres above sea level' (quoted from Rojana Industrial Park, 20I3). The project cost two billion Baht. ${ }^{4}$ Nearby, the Bang Pa Industrial estate constructed a wall $6.4 \mathrm{~m}$ tall and I $\mathrm{km}$ long. Alongside these walls, the project included a set of embankment dykes reinforcing the wall and twelve pumps to drain stagnant water (Chantana, 2012).

Residents in the area expressed concerns about the projects, but they were largely ignored. The same NGO which blocked the western floodway, the Stop Global Warming Association, filed an injunction with the central administrative court to slow the construction of the wall surrounding the hi-tech industrial estate. The injunction was on behalf of residents in the area and due to their concerns that the flooding would damage nearby homes. Refuting the call for EIA, the secretary of the industrial estate association argued that an EIA was conducted in parallel with the construction and, posing the spectre of future catastrophe, he warned: 'If we have to wait for the new EIA to be approved, we won't have time in the event of floods and 300,000 to 400,000 
people working in those industrial estates will be affected. Who will be responsible for their losing income?' (quoted from Fernquest, 2012) The wall was completed in 2012.

In addition, after the 20I floods, the national government implemented policies to help large-scale manufacturers recover. For example, Yingluck initiated a program that gave up to I00,00o Baht $(\$ 3,300)$ in tax rebates to first-time auto buyers. The scheme was resoundingly popular: sales under the programme totalled almost one million cars. The measure helped the automobile industry, car dealers and gasoline companies to rebound more quickly. However, besides worsening traffic in Bangkok, the policy also increased the country's carbon emissions and the demand for new roads (Techawongtham, 2012).

What is notable in the cases of these heavily subsidised projects is the way that the division of space into wet and dry proceeded under an overtly economic logic that favoured industrial estates and either bypassed or ignored the concerns of local residents. As Whitington $(2013,320)$ points out, reading the flood as a 'model event' silenced residents' questions enabling a prescriptive logic that sought to stave off imagined losses in a future of worsening events. Yet, such projects helped revive local and especially international investors' confidence by demonstrating state commitment to protecting industrial assets at all costs. The coalition of industrial estate owners and state agents argued that these estates had a broad economic importance and, thus, protecting them was a social good. That assumed social good outweighed the concerns of local residents, thereby potentially consigning them to inundated futures. The splintering effect of the walls on both urban space and future disasters is clear: extensive efforts to protect these economic interests has not only increased vulnerability to floods of those outside the constructed walls, including those downstream in Bangkok, but enhanced uncertainties.

\section{Conclusion: the enduring allure of disaster infrastructure}

While the floodwalls we describe here have been or are planned to be built in different locations in the BMR by government agencies at differing levels, and different groups oppose them, a number of similarities exist. They were all planned or built in an autocratic and non-participatory manner. While the government held a public hearing in Nakhon Pathom, it had already decided to build the project. Agencies have yet to conduct any EIAs for these projects or conducted them concurrently during construction. This suggests that the projects' proponents have decided to proceed with the projects quickly without examining the projected social or environmental impacts. Moreover, these cases suggest that decentralisation is incomplete (Marks and Lebel, 20I6). The central government is more powerful than provincial and local governments who oppose the projects, but feel powerless to stop them. Even at the national level, government agencies, such as the DRR and RID felt compelled to follow the 
orders of national political leaders even if they disagreed with them. These uneven relations between levels of government and authorities shape the decision-making processes governing flood infrastructure and limit the possibilities to resist higher-level authorities and the infrastructures themselves. Fragmented power structures make it difficult for citizens, civil society activists and state agents to oppose these projects, certainly after they have already been built. Moreover, the promise of flood infrastructure effectively re-maps urban space, as in Pakkret, producing sites that support state projects and new sites of exclusion. While activists and local government leaders in Nakhon Pathom and neighbouring provinces were able to successfully halt the planned western floodway, so far, they have been unsuccessful in changing the location or height of the dykes after they had been built or raised. One local government leader declared: 'Whether we accept the road or not, it has already been built. We cannot say anything.' Given the ad hoc nature of their construction and their uncertain effects, why are Thai government agencies expanding plans to build fractured flood infrastructures?

First, to please the electorate, the Yingluck government, as well as locally elected governments, built floodwalls ad hoc. According to a DRR officer, raising the roads on the northern and western outskirts of the BMR was a 'Pheu Thai party policy to make people choose them during the next election. They are showing the people they are trying to fix [the flood] problem as quickly as possible.' Pheu Thai leaders sought to convince voters in inner Bangkok that they are making an effort to protect Bangkok and will prevent future flooding. Floodwalls and dykes are easy for beneficiaries to observe and they can be located in areas to target favoured constituencies (Keefer, 2009). Additionally, these leaders hoped that these projects would please voters by stimulating the economy, which had suffered heavily in 20I. Here, the projects reflect efforts on behalf of the central government to produce new kinds of publics, like we saw in the Pakkret case, reconstituting its electorate in the process.

Second, building floodwalls can become a lucrative source of rents: politicians may give contracts for infrastructure projects to their key supporters, or earn money from bribes. Infrastructure can increase the value of flood-protected land to owners, which exclusively benefits the landowners rather than taxpayers (Keefer, 2009). In the case of raising the roads in BMR, the Yingluck government not only hired engineering companies as consultants to design these projects, but also contracted construction companies to carry out those projects. These companies are primarily owned by key supporters of Pheu Thai. Further, according to a Nakhon Pathom provincial council member we interviewed, these projects solidify relationships between politicians and certain bureaucrats. Politicians allocate large budgets to their allies in the bureaucracy, who then gain prestige and opportunities to collect rents by using these budgets to build these projects.

Third, local governments build floodwalls in response to other local governments 
building floodwalls upstream or across the river. Since Thailand has not effectively decentralised, post-flood politics demonstrate the ways in which splintered systems of authority affect post-disaster responses. As one local government head in Nakhon Pathom said: 'It is difficult not to build dykes because everywhere else is doing it. If we do not do it, we will not have anywhere to provide shelter and food to victims.' This official also recognised that building dykes ad hoc 'will make the situation worse. The water will come faster and harder.' However, government units do not coordinate with each other on flood protection plans. Subsequently, once upstream units start building them, a domino effect ensues: other units build dykes as well. For example, after 20I I, once the provincial government in Suphanburi Province built dykes upstream along the Ta Chin River, government units downstream, including in Nakhon Pathom, followed suit. A local government official in Nakhon Pathom stated: 'Everybody is trying to block the water from Suphanburi to here.' One reason no coordination exists is that the Disaster Prevention Law grants power to local administrative organisations to prevent disasters.

In all three cases we described here, the effects of the dykes are likely to be uneven. The losers will emerge during the event itself and likely to be those most on the peripheries of their geographic locations. In the first case, these people live in the outskirts of a city. In the second and third cases, they are mostly farmers who live in Ayutthaya or the outskirts of Bangkok beyond the walls of the industrial zone. These peripheries are considered the least economically valuable part of the EBMR. However, not all of these victims have been passive. Some have protested, signed petitions, and sued the government. The winners are those who live or work in the urban centres or own industrial estates. For example, Muang Thong Thani, a complex consisting of an arena, convention centre and exhibition hall in Pakkret, stayed dry in 20 I and will be further protected by the proposed dyke. Likewise, the inner city of Bangkok stayed dry in $201 \mathrm{I}$ and the raised roads were built with the goal of further protecting the inner city in the future. These floodwalls criss-cross socioeconomic classes, protecting both the poor and rich who live in inner Bangkok, while potentially exposing farmers and peri-urban farmers, who belong to all socioeconomic classes, to future floods.

These flood mitigation projects and the relationships they propose with Bangkok's hydrological landscape are of deeply fragmented, splintering nature, remaking local communities, transforming the polity and producing uncertain effects on future disasters. Through a broader lens, the geography of flood infrastructure demonstrates the ways that contemporary flood mitigation projects do not foreclose future floods, but instead, redistribute nature, risk and injury in an ad hoc manner. In the three cases we presented, the redistribution has been made along the lines of industrial estates and farmland, urban and rural, and central and outer urban communities. We suggest that the recent turn towards infrastructures within the social sciences (Graham and Marvin, 200I; Larkin, 20I3; Jensen and Morita, 20I6) is critical to making sense of 
post-disaster political ecologies. Attention to the processes through which infrastructures come into being, their spatiality, and their long-term effects helps unpack by what means nature and harm are redistributed in rapidly changing ecological zones. The examples of the floodwalls as discussed here suggest that disaster infrastructures do not merely mitigate future disasters, but instead splinter their effects in ways that are both knowable and unknowable. As the effects of climate change accumulate, attention to infrastructural efforts to secure certain places at the expense of others will be critical. Indeed, if these case studies accurately reflect those conditions, we can anticipate that such projects will redistribute class privilege, create unequal harm, and, in some places, engender new kinds of political conflicts that reflect emerging topographies and hydrologies of injury and harm.

\section{Notes}

Quotes are from twenty-six interviews conducted by the first author with community leaders, government officials and activists from January to May 2015.

We would like to acknowledge the assistance of Vanessa Lamb and John Connell who gave helpful comments and Trina Isorena who kindly created a map. We also thank the assistance of the Thailand Development Research Institute (TDRI). The project benefited from the financial support of an International Development Research Centre grant to TDRI to support improved flood management planning in Thailand. Additionally, we acknowledge the support of the Asia Research Institute. The project also benefited from the financial support of a Singapore Ministry of Education Academic Research Fund Tier 2 grant entitled 'Governing Compound Disasters in Urbanising Asia' (MOE20I4-T2-I-OI7).

Finally, we acknowledge the financial support provided to make this special issue 'open access' by Canada's 'Water in the city: community participation and water access in southeast Asian cities' project funded by the Social Science and Humanities Research Council (SSHRG) (Award reference number: 435-2012-o638).

\section{References}

Anand, N. (20 I) 'PRESSURE: the politechnics of water supply in Mumbai', Cultural Anthropology, 26(4), 542-64.

Anand, N., Gupta. A. and Appel, H. (2018) The promise of infrastructure, Durham, NC, Duke University Press.

Attakhor, P. (2013) 'Samut Songkhram pressures govt over water project', Bangkok Post, 25 November 2013 .

Bennett, J. (2010) 'Thing-power', in Sarah Whatmore and Bruce Braun (eds) Political matter: technoscience, democracy, and public life, Minneapolis: University of Minnesota Press, 35-62. 
Chantana, A. (2012) 'New flood barrier at Bang Pa-in Industrial Park "ahead of schedule", The Nation, io July 2012.

Choi, V. Y. (2015) 'Anticipatory states: tsunami, war, and insecurity in Sri Lanka', Cultural Anthropology, 30(2), 286-309.

Cleanbiz.Asia (2013) 'Strong whiff of corruption from Thailand's water mega-project', Cleanbiz. Asia, 21 February 2013.

Collins, T. W. (2010) 'Marginalization, facilitation, and the production of unequal risk: the 2006 Paso Del Norte floods', Antipode, 42(2), 258-88.

Connolly, W. E. (2013) The fragility of things: self-organizing processes, neoliberal fantasies, and democratic activism, Durham, NG, Duke University Press.

Cook, I. R. and Swyngedouw, E. (2012) 'Cities, social cohesion and the environment: towards a future research agenda', Urban Studies, 49(9), I959-79.

Elinoff, E. (2017a) 'Ecologies of possibility: dwelling, politics, and government along Khon Kaen's railway tracks', in A. Rademacher and K. Sivaramakrishnan (eds) Places of nature in ecologies of urbanism, Hong Kong, Hong Kong University Press.

Elinoff, E. (2017b) 'Concrete and corruption', City, 2I(5), 587-96.

Elinoff, E. and Sopranzetti, C. (2012) 'Introduction to special focus: provincialising Bangkok: Isan from "not yet" to "now", South East Asia Research, 20(3), 299-303.

Elinoff, E., Sur, M. and Yeoh, B. (2017) 'Constructing Asia', City, 2 I(5), 580-86.

Fernquest, J. (20I I) 'Bangkok's drainage system', Bangkok Post, i November 20I I, http:/ /www. bangkokpost.com/learning/learning-from-news/264228/bangkok-drainage-system (accessed io July 20I8).

Fernquest, J. (2012) 'YAFF: yet another floodwall fight', Bangkok Post, 6 March 2012, http:// www.bangkokpost.com/learning/learning-from-news/283 $6_{5}$ /yaff-yet-another-floodwall-fight (accessed Io July 20I8).

Graham, S. and Marvin, S. (200I) Splintering urbanism: networked infrastructures, technological mobilities and the urban condition, London, Routledge.

Graham, S. and Thrift, N. (2007) 'Out of order understanding repair and maintenance', Theory, Culture \& Society, 24(3), I-25.

Guggenheim, M. (2014) 'Introduction: disasters as politics - politics as disasters', The Sociological Review, 62(I_suppl), I-I6.

Harvey, P. and Knox, H. (2012) 'The enchantments of infrastructure', Mobilities, 7(4), 52I-36.

Janseen, P. (2013) 'Two years after deluge, Thailand braces for more floods', Oman Observer, 29 September 2013, http://20I6.omanobserver.om/two-years-after-deluge-thailandbraces-for-more-floods/ (accessed Io July 2018).

Jensen, C. B. and Morita, A. (2016) 'Infrastructures as ontological experiments', Ethnos, January, $\mathrm{I}-\mathrm{I} 2$.

Keefer, P. (2009) 'Disastrous consequences: the political economy of disaster risk reduction', World Bank Working Paper, Washington DC, World Bank.

Larkin, B. (2013) 'The politics and poetics of infrastructure', Annual Review of Anthropology, 42(I), $327-43$.

Liao, K-H. (2012) 'A theory on urban resilience to floods: a basis for alternative planning practices', Ecology \& Society, I7(4), 627-40. 
MacCallum, D., Steele, W., Byrne, J. and Houston, D. (201 I) 'Environmental imaginaries: climate change as an object of urban governance', Conference Paper, State of Australian Cities, November 201 I, Melbourne.

Manuta, J., Khrutmuang, S., Huaisai, D. and Lebel, L. (2006) 'Institutionalized incapacities and practice in flood disaster management in Thailand', Science and Culture, 72(I/2), Io, IO-22.

Marks, D. (20I5) 'The urban political ecology of the 20I I floods in Bangkok: the creation of uneven vulnerabilities', Pacific Affairs, 88(3), 623-51.

Marks, D. (2019) "We are quality citizens of Bangkok too": urban activism in Bangkok during the 20r f floods', in N. M. Yip, M. A. Martínez López and X. Sun (eds) Contested cities and urban activism, Singapore, Springer Singapore, 229-52.

Marks, D. and Lebel, L. (2016) 'Disaster governance and the scalar politics of incomplete decentralization: fragmented and contested responses to the 20I I floods in central Thailand', Habitat International, 52(March), 57-66.

McFarlane, C. (2010) 'Infrastructure, interruption, and inequality: urban life in the global South', in S. Graham (ed.) Disrupted cities: when infrastructure fails, New York, Routledge, $\mathrm{I} 3 \mathrm{I}-44$.

Miller, M. A. and Douglass, M. (2015) 'Introduction: governing flooding in Asia's urban transition', Pacific Affairs, 88(3), 499-5'5.

NBC News (20I I) 'As the floods recede, Bangkok blame game begins', $N B C$ Newes, 22 November $201 \mathrm{I}$.

Pelling, M. and Dill, K. (2010) 'Disaster politics: tipping points for change in the adaptation of sociopolitical regimes', Progress in Human Geography, 34(I), 2 I-37.

Phongpaichit, P. and Baker, C. (2015) Unequal Thailand: aspects of income, wealth and power, Singapore, NUS Press.

Poapongsakorn, N. and Meethom, P. (2013) 'Impact of the 20I I floods, and flood management in Thailand', ERIA Discussion Paper Series 34.

Rojana Industrial Park (20I3) 'Rojana Ayutthaya project', 4 November 20I3, http://www. rojana.com/ayutthaya_project.html (accessed Io July 20I8).

Star, S. L. (I999) 'The ethnography of infrastructure', American Behavioral Scientist, 43(3), 377-9I.

Techawongtham, W. (2012) 'Carbuyer scheme is shamefulwaste', Bangkok Post, 2 I December 2012, https://www.bangkokpost.com/opinion/opinion/3272 I4/first-time-car-buyer-schemea-shameful-waste (accessed io July 2018).

Thailand Development Research Institute (20I5) 'การประชุมเชิงปฏิบัติการ โครงการป้องกันและแก้ไขปัญหาอุ ทกภัยบริเวณทุ่งพระพิมล...ผลได้-ผลเสีย.' ('Workshop to prevent and solve flood problems in Thung Prapimorn'), Salaya, Thailand, March 27.

Thongchai, W. (1994) Siam mapped: a history of the geo-body of a nation, Honolulu, University of Hawaii Press.

van Voorst, R. and Hellman, J. (2015) 'One risk replaces another', Asian Fournal of Social Science, $43(6), 786-8$ го.

Whitington, J. (2013) 'Fingerprint, bellwether, model event: climate change as speculative anthropology', Anthropological Theory, i3(4), 308-28. 
World Bank (201 I) 'The World Bank supports Thailand's post-floods recovery effort', The World Bank, I3 December 20II, http://www.worldbank.org/en/news/feature/20II/I2/I3/ world-bank-supports-thailands-post-floods-recovery-effort.

World Bank (2012) 'Thai flood 20ı I: rapid assessment for resilient recovery and reconstruction planning (Vol. 2 of 2): final report (English)', Bangkok, World Bank.

Zeiderman, A. (2015) 'Spaces of uncertainty: governing urban environmental hazards', in L. Samimian-Darash and P. Rabinow (eds) Modes of uncertainty: anthropological cases, Chicago, University of Chicago Press, I82-200. 